\title{
DETERMINATION OF TOTAL FLAVONOID LEVELS ON ALPUKAT FRUIT SKIN (PERSEA AMERICANA MILL.)
}

\author{
Firlia dan Sri Hastuti
}

\author{
Jurusan Pendidikan MIPA \\ Fakultas Keguruan dan IImu Pendidikan Universitas Tadulako Palu
}

\begin{abstract}
Avocados (Persea americana Mill) are fruits that originally from Mexico and Central America. It has the characteristics of green flesh on the bottom of the skin and yellowing toward the seeds with a texture that is rather soft when it is ripe. Skin color varies, some are green because of chlorophyll or black content due to anthocyanin pigments. This study aimed to determine the total levels of flavonoids in the skin of avocados that were green and black. Determination of total flavonoid levels used a UV- Vis spectrophotometer. The results showed that an analysis of water content was $5.306 \%$ for green avocado skin and $7.327 \%$ for black avocado skin. The analysis of total flavonoid levels at a wavelength of $437 \mathrm{~nm}$ obtained respectively, the average yield was 54,950 $\mathrm{mg} / 100 \mathrm{~g}$ for green avocado skin and 29,519 $\mathrm{mg} / 100 \mathrm{~g}$ for black avocado skin. The results of this study are expected to be able to attract the interest of the community to cultivate green and black avocado plants. especially in the area of Central Sulawesi.
\end{abstract}

Keywords: Black and green avocado skin, flavonoids, UV-Vis spectrophotometer.

\section{PENDAHULUAN}

Indonesia terkenal dengan keanekaragaman jenis buah dan negara yang memiliki kekayaan alam dengan berbagai jenis tanaman yang berkhasiat sebagai obat tradisional. Salah satunya adalah buah alpukat (Persea americana Mill.). Alpukat (Persea americana Mill.) merupakan tanaman yang dapat tumbuh subur di daerah tropis seperti Indonesia (Feliana, dkk. 2018). Buah- buahan yang berwarna cerah umumnya memiliki aktivitas antioksidan yang baik bagi tubuh diantaranya buah alpukat (Rahmi, 2017). Kulit alpukat merupakan limbah yang memiliki banyak khasiat yang dapat bermanfaatkan bagi manusia (Fauziah, 2016). Alpukat tidak mengandung kolestrol atau sodium dan rendah lemak jenuh (Antasionasti, 2016) .

Kulit alpukat mengandung senyawa flavonoid yang dapat digunakan untuk melindungi kulit terhadap sinar UV atau mampu mengurangi kerusakan kulit (Mokodompit et al., 2013). Buah alpukat yang masak memiliki kandungan metabolit sekunder (flavonoid, tanin dan antosianin) yang lebih besar pada biji dan kulit buahnya dibandingkan pada buah alpukat yang masih muda (Yachya \& Sulistyowati, 2015). Demikian juga kulit ekstrak alpukat mempunyai beberapa kandungan karotein, fenolik total, dan flavonoid yang lebih tinggi dari pada daging buahnya (Vinha et al., 2013).

Kulit buah alpukat memiliki aktivitas antibakteri (Wulandari et al., 2019). Diketahui sebagai antibakteri karena kandungan senyawa antibakteri seperti saponin, alkaloid, dan flavonoid pada buah dan daunnya (Ernawati, 2015).

Salah satu kandungan senyawa yang terdapat di dalam buah-buah tersebut adalah senyawa flavonoid (Febrianti \& Sari, 2016). Flavonoid merupakan suatu bahan aktif yang dapat berperan sebagai antioksidan (Wahyuni, 2019). Antioksidan dapat menjadi strategi ampuh untuk mengurangi kerusakan akibat radikal bebas (Dikici et al., 2017).Flavonoid juga dapat menangkap radikal bebas yang dapat merusak sel tubuh (Shinta, 2018). Pada kulit buah alpukat kandungan kimianya yang lebih berperan yaitu flavonoid karena merupakan salah satu senyawa golongan fenol alam yang terbesar yang terdapat dalam semua tumbuhan hijau (Jayustin \& Fratama, 2019). Kulit buah alpukat juga dapat digunakan untuk sintesis nanopartikel perak (Agnes Rantesalu, 2019).

Flavonoid adalah pigmen tumbuhan yang memberikan manfaat kesehatan bagi konsumen manusia dan hewan (Paauw et al., 2019). Analisis tersebut digunakan untuk melakukan uji secara kuantitatif untuk menentukan jumlah flavonoid yang terdapat dalam ekstrak yang dilakukan dengan mengukur nilai absorbansinya. Absorbansi dan kadar flavonoid memiliki hubungan yang linear, yaitu semakin tinggi absorbansi yang terukur maka kadar flavonoid yang terkandung didalam suatu tanaman juga semakin tinggi (Aminah et al., 2017).

Berdasarkan uraian diatas untuk meningkatkan pemanfaatan kulit buah alpukat sebagai sumber obat tradisional, maka peneliti tertarik untuk meneliti kadar flavonoid total yang terkandung pada ekstrak kulit buah alpukat hijau dan hitam dengan menggunakan metode 
spektrofotometri UV-Vis, untuk membandingkan kulit buah alpukat manakah yang memiliki kadar flavonoid lebih besar yang berpotensi sebagai obat.

\section{METODE PENELITIAN}

\section{Alat dan bahan}

Alat-alat yang digunakan pada penelitian ini yaitu pipet tetes, tabung reaksi, neraca digital, spatula, Erlenmeyer $100 \mathrm{~mL}$, mikro pipet, gelas kimia $100 \mathrm{~mL}$, labu ukur $50 \mathrm{~mL}$, shaker, corong, kertas saring, gelas ukur $100 \mathrm{~mL}$, rak tabung reaksi, oven, cawan, penjepit, wadah, kuvet, spektrofotometer UV-Vis, sendok, desikator, blender dan gunting.

Bahan yang digunakan pada penelitian ini yaitu sampel ekstrak kulit buah alpukat hijau dan hitam (Persea americana Mill), etanol $95 \%$, etanol $96 \%$, aluminium foil, tissue, aluminium klorida $(\mathrm{AlCl} 3) 10 \%$, kalium asetat, aquades, standar kuarcetin konsesntrasi 20 ppm, 40 ppm, $60 \mathrm{ppm}, 80 \mathrm{ppm}, 100 \mathrm{ppm}$. Alat yang digunakan pada penelitian ini yaitu palu-palu, lumpeng dan alu, cawan porselin, ayakan 70 mesh, oven, neraca analitik, desikator, serta seperangkat alat XRF. Bahan yang digunakan pada penelitian ini yaitu batuan dari pertambangan emas rakyat Poboya dan aquades.

\section{Penyiapan sampel}

Buah alpukat yang berwarna hijau dan hitam pada tahap ini dikupas dan diambil kulitnya lalu di cuci sampai bersih menggunakan air mengalir. Setelah itu kulit alpukat hijau dan hitam dipotong kecil-kecil, selanjutnya dikeringkan dengan cara diangin-anginkan selama seminggu pada suhu ruang dengan tidak terkena sinar matahari langsung. Setelah kering sampel ditimbang dan dicatat berat keringnya kemudian diserbukkan setelah itu ditimbang kembali berat sampel serbuk yang di peroleh (Rizki, dkk. 2016).

\section{Penentuan kadar flavonoid total}

Penetapan kadar flavonoid total dengan metode kolorimetri yang mengacu pada prosedur (Chang et al., 2002) dan (Ahmad et al., 2014) dengan beberapa modifikasi dengan kuersetin (QE) sebagai standar.

\section{a. Penentuan panjang gelombang maksimum ( $\lambda$ maks) kuarsetin}

Penentuan panjang gelombang maksimum kuarsetin dengan running larutan kuarsetin pada range panjang gelombang 400-500 nm. Hasil running menunjukkan panjang gelombang maksimum standar baku kuarsetin berada pada panjang gelombang $437 \mathrm{~nm}$. Panjang gelombang maksimum tersebut yang digunakan untuk mengukur serapan dari sampel ekstrak kulit buah alpukat (persea americana Mill.).

\section{b. Pembuatan larutan standar kuersetin}

Ditimbang $10 \mathrm{mg}$ standar baku kuersetin kemudian dimasukkan ke dalam labu ukur $50 \mathrm{~mL}$, ditambahkan etanol $95 \%$ sampai tanda batas (larutan induk $1000 \mathrm{mg} / \mathrm{L}$ ). Kemudian dibuat serangkaian larutan standar 20, 40,60, 80, dan $100 \mathrm{mg} / \mathrm{L}$. Pipet masing-masing larutan standar 1 $\mathrm{mL}$, lalu tambahkan $1,5 \mathrm{~mL}$ etanol $95 \%, 0,5 \mathrm{~mL}$ aluminium klorida (AICl3) $10 \%, 0,5 \mathrm{~mL}$ kalium asetat $1 \mathrm{M}$ dan tambahkan akuades $2,8 \mathrm{~mL}$. setelah itu, diinkubasi selama 30 menit pada suhu kamar. Absorbansi ditentukan menggunakan metode spektrofotometer UV-Vis pada panjang gelombang $437 \mathrm{~nm}$, kemudian dibuat kurva kalibrasinya.

\section{c. Penentuan kadar flavonoid total}

Menimbang sampel kulit buah alpukat hijau dan hitam sebanyak 1 gram menggunakan neraca digital. Kemuadian memasukan sampel kedalam erlenmeyer $100 \mathrm{~mL}$, lalu menambahkan etanol $96 \%$ sebanyak $50 \mathrm{~mL}$, sampai seluruh sampel terendam, kemudian ditutup dan dibiarkan selama 24 jam. Maserat disaring dengan menggunakan kertas saring. Filtrat diperoleh melalui penyaringan dengan corong, kemudian ampas dimaserasi kembali dengan etanol $96 \% 50 \mathrm{~mL}$, sehingga filtrat hampir tidak berwarna. Semua filtrat disatukan dan dipekatkan dengan menggunakan rotavapor sampai tidak ada lagi cairan yang menetes sehingga diperoleh ekstrak etanol kulit buah alpukat (Persea americana Mill.). Ekstrak kental kulit buah alpukat (Persea americana Mill.) yang didapatkan digunakan untuk dianalisis lebih lanjut.

Selanjutnya menambahkan etanol $95 \%$ sebanyak $1,5 \mathrm{~mL}$. Selanjutnya menambahkan aluminium klorida (AICl3) sebanyak $1 \mathrm{ml}$ pada tabung, lalu menambahkan kalium asetat $0,5 \mathrm{~mL}$ pada tabung. Kemudian menambahkan aquades sebanyak 2,8 ml pada tabung. Kemudian mendiamkan selama 30 menit, lalu menyaring kembali larutan untuk memisahkan filtrat dan residu.kemudian memasukan filtrat kedalam kuvet kemudian diukur nilai serapannya menggunakan alat spektrofotometri UV-Vis dengan panjang gelombang $437 \mathrm{~nm}$ penentuan total flavonoid dengan metode kolorimetri.

\section{ANALISA DATA}

\section{Menentukan Kadar Air}

Teknik analisa data pada penelitian ini terlebih dahulu dilakukan dengan menentukan kadar air :

$$
\begin{aligned}
& \% \text { Kadar air }=\frac{\{(B S-(\text { rata }- \text { rata pengovenan }-B S)\}}{B S} \times 100 \% \\
& \text { Menentukan Kadar Flavonoid }
\end{aligned}
$$

Data larutan standar ini digunakan untuk membuat persamaan regresi yaitu persamaan yang digunakan untuk menghitung kadar flavonoid :

$$
y=a x+b
$$




$$
\mathrm{F}=\frac{C \cdot V}{m} x 100
$$

Dimana $F=$ Kadar flavonoid total $(\mathrm{mg} / 100 \mathrm{~g})$, bahan $\mathrm{x}$ adalah konsentrasi sampel $(\mathrm{mg} / \mathrm{L}), \mathrm{V}$ adalah volume $(\mathrm{L})$ dan $\mathrm{m}$ adalah massa sampel (g).

\section{HASIL DAN PEMBAHASAN}

Tumbuhan alpukat (Persea americana Mill.) yang digunakan dalam penelitian ini yaitu hanya pada bagian kulit buah alpukat. Kulit buah alpukat dapat digunakan sebagai bahan aktif tabir surya yaitu untuk melindungi kulit terhadap sinar UV atau mampu mengurangi kerusakan kulit, karena mengandung senyawa flavonoid (Mokodompit et al., 2013).

Flavonoid hampir terdapat pada semua bagian tumbuhan termasuk buah, akar, dan kulit luar batang. Flavonoid merupakan senyawa alam yang berpotensi sebagai antioksidan dan dapat menangkat radikal bebas yang berperan pada timbulnya penyakit degeneratif melalui mekanisme perusakan sistem imunitas tubuh, oksidasi lipid dan protein (Rais, 2015).

Pada penelitian ini buah alpukat yang digunakan diperoleh di sekitaran Kelurahan Tondo, Sulawesi Tengah. Kulit buah alpukat hijau dan hitam (Persea americana Mill.) dilakukan pengubahan bentuk dengan cara dipotong-potong kecil dan diangin-anginkan tujuannya untuk mempercepat proses pengeringan sehingga mengurangi kadar air yang terdapat pada sampel dan dapat mencegah pembusukan oleh bakteri.

Setelah kering sampel kulit buah alpukat hijau dan hitam berwarna hijau kecoklatan dan hitam kecoklatan, kemudian sampel dihaluskan sampai menjadi serbuk,.kemudian hasil pada sampel kulit buah alpukat ditimbang, untuk kulit buah alpukat hijau sebesar 6 gram berwarna coklat muda dan untuk kulit buah alpukat hitam sebesar 6 gram berwarna coklat tua. Kemudian selanjutnya dilakukan penentuan pada kadar air dari sampel tersebut.

\section{Analisis kadar flavonoid pada Kulit Buah Alpukat Hijau dan Hitam}

Penentuan kadar flavonoid total di awali dengan proses ekstraksi. Proses ekstraksi dilakukan terkandung dalam sampel. Prinsip ekstraksi didasarkan pada perpindahan masa komponen zat yang terlarut kedalam pelarut sehingga terjadi perpindahan pada lapisan antar muka dan berdifusi masuk kedalam pelarut (Harbone, J.B. 1987). Semakin lama waktu ekstraksi, maka kadar total flavonoid semakin meningkat. Hal ini terjadi karena semakin lama proses ekstraksi, maka kontak antara pelarut dengan zat terlarut semakin lama dan pada waktu tertentu akan mencapai titik kesetimbangan (Yue. 2015). Menurut (Adawiah, 2015) bahwa flavonoid larut pada pelarut aquades, etanol dan methanol.Pelarut yang digunakan pada penelitian ini adalah etanol $96 \%$ sebagai pelarut polar. Dalam hal penyarian etanol digunakan karena memiliki kelebihan dibandingkan dengan air dan metanol. Senyawa kimia yang mampu disari dengan etanol lebih banyak dari pada penyari metanol dan air. Hasil ekstraksi kulit buah alpukat hijau berwarna hijau bening dan buah alpukat hitam berwarna coklat bening.

Pada penelitian ini untuk menentukan kadar flavonoid total pada sampel kulit buah alpukat hijau dan hitam, dilakukan dengan pembuatan standar kuarsetin dengan deret konsetrasi larutan standar 20, 40, 60, 80 dan 100 ppm.

Digunakan deret konsentrasi karena metode yang dipakai dalam menentukan kadar adalah metode yang menggunakan persamaan

kurva baku, untuk membuat kurva baku terlebih dahulu dibuat beberapa deret konsentrasi untuk mendapatkan persamaan linear yang dapat digunakan untuk menghitung persen kadar. Digunakan kuarsetin sebagai larutan standar karena kuarsetin merupakan flavonoid golongan flavonol yang mempunyai gugus keto pada C-4 dan memiliki gugus hidroksi pada atom C-3 atau C-5 yang bertetangga dari flavon dan flavonol (Azizah et al., 2014). Pengukuran serapan panjang gelombang maksimum dilakukan running dari panjang gelombang 400-500 nm. Hasil running menunjukan panjang gelombang maksimum standar baku kuarsetin berada pada panjang gelombang $437 \mathrm{~nm}$. Panjang gelombang maksimum tersebut yang digunakan untuk mengukur serapan dari sampel ekstrak kulit alpukat hijau dan hitam (Persea americana Mill.).

Kurva larutan standar kuersetin dibuat dengan mengasumsikan bahwa sumbu $x$ adalah konsentrasi larutan kuersetin dan sumbu $y$ merupakan absorbansi larutan kuersetin. Kurva ini akan digunakan untuk menentukan kadar flavonoid total sampel. 
Tabel 1. Hasil pengukuran absorbansi larutan standar kuersetin pada panjang gelombang maksimum 437 nm.

\begin{tabular}{cc}
\hline Konsentrasi $(\mathrm{ppm})$ & Absorbansi $(\mathrm{y})$ \\
\hline 20 & 0,192 \\
40 & 0,385 \\
60 & 0,598 \\
80 & 0,792 \\
100 & 1,022 \\
\hline
\end{tabular}

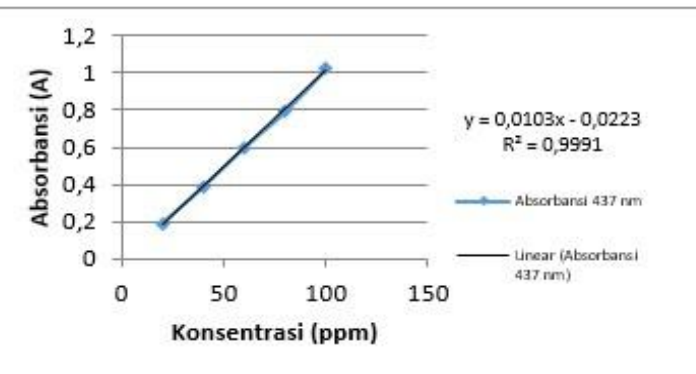

Gambar 1. Kurva kalibrasi kuersetin pada panjang gelombang maksimum $435 \mathrm{~nm}$

Dari pengukuran tersebut, dapat disimpulkan bahwa semakin tinggi konsetrasi yang digunakan maka semakin tinggi pula absorban yang di peroleh. Hasil standar kuarsetin yang diperoleh dari kurva standar kuarsetin, sehingga diperoleh persamaan regresi linear yaitu $y=0,0103 x$ 0,0223 dengan nilai $R^{2}$ yang diperoleh sebesar = 0,9991 dan nilai $r$ mendekati 1. Persamaan kurva kalibrasi kuarsetin dapat digunakan sebagai pembanding untuk menentukan konsentrasi senyawa flavonoid total pada ekstrak sampel kulit alpukat hijau dan hitam.

Pada pengukuran senyawa flavonoid total $\mathrm{AICl} 3$ yang dapat membentuk senyawa kompleks, sehingga terjadi pergeseran panjang gelombang kearah visible (tampak). Dan penambahan kalium asetat yang bertujuan untuk mempertahankan panjang gelombang pada daerah visible (tampak)
(Chang et al., 2002). Dan untuk mendeteksi adanya gugus 7 hidroksi.

Setelah pendiaman selama 30 menit larutan berwarna putih keruh dan kuning keruh. Perlakuan inkubasi selama 30 menit sebelum pengukuran dimaksudkan agar reaksi berjalan sempurna, sehingga intensitas warna yang dihasilkan lebih maksimal (Azizah et al., 2014). Kemudian hasil penyaringan kedua sampel larutan berwarna bening.

Pengujian analisis kadar flavonoid dengan menggunakan spektrofotometri UV-Vis digunakan larutan blanko sebagai kontrol yang berfungsi sebagai pemblank ( mengkali nol-kan) senyawa yang tidak perlu dianalisis. Sehingga hasil penelitian didapatkan rata-rata kulit buah alpukat hijau sebesar $54,950 \mathrm{mg} / 100 \mathrm{~g}$ dan untuk kulit buah alpukat hitam sebesar 29,519 mg/100g.

Tabel 2. Data kadar flavonoid total

\begin{tabular}{|c|c|c|c|c|c|}
\hline Sampel & Perlakuan & Absorbansi & $\begin{array}{c}\text { Konsentrasi } \\
\text { Flawonoid (mg L) }\end{array}$ & $\begin{array}{l}\text { Kadar Flavonoid } \\
(\mathrm{mg} / 100 \mathrm{~g})\end{array}$ & $\begin{array}{c}\text { Rata-rata Kadar } \\
\text { Flavonoid } \\
(\mathrm{mg} / 100 \mathrm{~g})\end{array}$ \\
\hline \multirow{3}{*}{ Alpukat kulit hitam } & 1 & 0,023 & 4,500 & 22,388 & \multirow{3}{*}{29,519} \\
\hline & 2 & 0,035 & 5,700 & 28,358 & \\
\hline & 3 & 0,054 & 7,600 & 37,811 & \\
\hline \multirow{3}{*}{ Alpukat kulit hijau } & 1 & 0,078 & 10,000 & 49,505 & \multirow{3}{*}{54,950} \\
\hline & 2 & 0,091 & 11,300 & 55,941 & \\
\hline & 3 & 0,098 & 12,000 & 59,406 & \\
\hline
\end{tabular}

\section{KESIMPULAN}

Berdasarkan hasil penelitian yang telah dilakukan dapat disimpulkan bahwa kadar flavonoid total dari ekstrak kulit alpukat hijau dan hitam (Persea americana Mill.) yaitu hijau sebesar $54,950 \mathrm{mg} / 100 \mathrm{~g}$ dan hitam sebesar 29,519 mg/100g.

\section{UCAPAN TERIMA KASIH}

Penulis mengucapkan terima kasih kepada pihak yang telah membantu penelitian ini, khususnya kepala Laboratorium Kimia Fakultas Keguruan dan Ilmu Pendidikan dan Kimia Fakultas Matematika dan IImu Pengetahuan Alam 
Universitas Tadulako, sehingga penelitian ini berjalan dengan baik.

\section{DAFTAR PUSTAKA}

[1] Adawiah, A. R. R. (2015). Ekstraksi Flavonoid metode Soxhletasi dari batang pohon pisang ambon ( Musa paradisiaca var sapientum ) dengan berbagai jenis pelarut. Snips, 625-628.

[2] Agnes Rantesalu, T. G. O. (2019). Sintesis nanopartikel perak menggunakan kulit alpukat (persea americana) dengan dan tanpa pemanasan. Jurnal Kesehatan,12(1), 175-178.

[3] Ahmad, A. R., Sakinah, Wisdawati, \& Asrifa, W. O. (2014). Study of antioxidant activity and determination of phenol and flavonoid content of pepino's leaf extract (Solanum muricatum aiton). International Journal of PharmTech Research, 6(2), 600-606.

[4] Aminah, A., Tomayahu, N., \& Abidin, Z. (2017). Penetapan kadar flavonoid total ekstrak etanol kulit buah alpukat (persea americana mill.) dengan metode spektrofotometri uv-vis. Jurnal Fitofarmaka Indonesia, $\quad 4(2)$, 226-230. https://doi.org/10.33096/jffi.v4i2.265

[5] Antasionasti, I. (2016). Penentuan Aktivitas dan Identifikasi Senyawa Aktif Antioksidan dalam Kulit Buah Alpukat .(Issue lii, pp. 73-74).

[6] Azizah, D. N., Kumolowati, E., \& Faramayuda, F. (2014). Penetapan kadar flavonoid metode alcl3 pada ekstrak metanol kulit buah kakao (theobroma cacao I.). Kartika Jurnal IImiah Farmasi, 2(2), 45-49. https://doi.org/10.26874/kjif.v2i2.14

[7] Chang, C. C., Yang, M. H., Wen, H. M., \& Chern, J. C. (2002). Estimation of total flavonoid content in propolis by two complementary colometric methods. Journal of Food and Drug Analysis, 10(3), 178-182.

[8] Dikici, E., Tohma, H., Köksal, E., \& Işık, M. (2017). Antioxidant Activity and Total Phenolic/Flavonoid Contents of Phlomis pungens L. Hacettepe Journal of Biology and Chemistry, 3(45), 425-433.https://doi.org/10.15671/hjbc. 2018.184

[9] Fauziah, N. A., \& Saleh, Chairul, E. (2016). Ekstraksi dan uji stabilitas zat warna dari kulit buah alpukat (Persea americana Mill) dengan metode Spektroskopi UV-VIS. Jurnal Atomik, 1(1), 12-37. http://jurnal.kimia.fmipa.unmul ac.id/i ndex.php/JA/article/view/180

[10] Febrianti, N., \& Sari, F. J. (2016). Kadar Flavonoid Total Berbagai Jenis Buah. Prosiding Symbion, 607-612.

[11]Fei-Yue Ma, Xiu-Mei Zhang, , Yu-Ge Liu, Qiong Fu, Z.-L. M. (2015). Comparison of Different Extraction Methods for Flavonoids and Polyphenols from Manilkara Zapota Leaves and Evaluation of Antioxidant Activity. International Symposium on Energy Science and Chemical Engineering (ISESCE), 171175. 15.2015 .34

[12] Feliana, Kiki, Sri Mursiti, dan H. (2018). View of Isolasi dan Elusidasi Senyawa Flavonoid dari Biji Alpukat (Persea americana Mill. Indo. J. Chem. Sci,7(2).

[13] Jayustin, M., \& Fratama, A. P. (2019). Uji Efektivitas Antibakteri Dengan Kulit Buah Alpukat (Persea americana Mill) Sebagai Objek Untuk Diambil Ekstraknya Dengan Bioindikator Bakteri Staphylococcus aureus. Jurnal Biosains, 5(2), 71-75.

[14] Mokodompit, A. ., Jaya, E., \& Wiyono, W. (2013). Penentuan Nilai Sun Protective Factor (SPF) Secara In Vitro Sunscreen cream Ekstrak Ethanol Kulit Alpukat. Pharmacon. 2(3)(03), 2302-2493.

[15]Paauw, M., Koes, R., \& Quattrocchio, F. M. (2019). Alteration of flavonoid pigmentation patterns during domestication of food crops. Journal of Experimental Botany, 70(15), 3719-3735. https://doi.org/10.1093/jxb/erz141

[16]Rahmi, H. (2017). Review: Aktivitas Antioksidan dari Berbagai Sumber Buahbuahan di Indonesia. Jurnal Agrotek Indonesia, 2(1), 34-38. https://doi.org/10.33661/jai.v2i1.721

[17] Rais, I. R. (2015). Etanolik herba sambiloto ( andrographis paniculata (burm .f .) ness ) isolation and determination of flavonoid content of (andrographis paniculata ( burm . f .) ness ) ethanolic herb. Pharmaçiana, 5, 100-106.

[18]Rizki Yulianti R, Amaliah Dahlia, A. R. A. (2016). Penetapan kadar flavonoid total dari ekstrak etanolik daun benalu mangga (dendrophthoe pentandra I. miq). Jurnal Fitofarmaka Indonesia, 1(1), 14-17. https://doi.org/10.33096/jffi.v1i1.195

[19] Sari, E. dan K. (2015). Kandungan senyawa kimia dan aktivitas antibakteri ekstrak kulit buah alpukat (persea americana p.mill) terhadap bakteri vibrio alginolyticus. Jurnal Kajian Veteriner, 97(12), 194-200.

[20] Shinta, D. (2018). Kandungan Flavonoid dan Aktivitas Antioksidan Ekstrak Pleurotus ostreatus. Jurnal rona Teknik Pertanian, 11(1), 1-10. https://doi.org/10. 17969/rtp.v11i1.9571

[21] Vinha, A. F., Moreira, J., Jorge, R. De, \& Ferreira, V. (2013). Physicochemical Parameters , Phytochemical Composition and Antioxidant Activity of the Algarvian Avocado ( Persea americana. Journal of Agricultural Science. Vol. 5, No. 12; 100-109. https://doi.org/10.5539/jas.v5n12p100

[22] Wahyuni, N. (2019). Pengaruh Suhu Terhadap Ekstraksi Flavonoid dari Kulit Buah 
Alpukat ( Persea Americana MILL .) dengan Pelarut Etanol. Skripsi. Universitas Sumatera Utara.

[23] Wulandari, G., Abdul Rahman, A., Rubiyanti, R., (2019). Uji Aktivitas Antibakteri Ekstrak Etanol Kulit Buah Alpukat (Persea americana Mill) terhadap Staphylococcus aureus ATCC 25923 Antibacterial Activity Of Avocados Peel (Persea americana Mill) Extract On
Staphylococcus aureus ATCC 25923. Studi DIII Jurusan Farmasi, P., Kemenkes Tasikmalaya, P., \& Email, I.15, 74-80.

[24] Yachya, A., \& Sulistyowati. (2015). Aktivitas anti bakteri biji dan kulit buah alpukat ( persea americana mill .) terhadap aerobacter aerogenes dan proteus mirabilis. Jurnal teknik waktu, 13(2),30-37. 